\title{
The Implementation of E-Learning for Students of Teacher Education Faculty: A Case Study in Esa Unggul University
}

\author{
Ainur Rosyid \\ \{ainur.rosyid@esaunggul.ac.id\} \\ Department of Elementary Teacher Education, Faculty of Education, Esa Unggul University, Jakarta, \\ Indonesia 11510
}

\begin{abstract}
The development of ICT has changed education through e-learning. Esa Unggul University has newly implemented e-learning, especially the department of Elementary Teacher Education. It aimed to investigate the factors influencing the implementation of e-learning for students of the Teacher Education Faculty. The case study method was implemented to conclude this research. The participants of this study were 50 students majoring in the department of Elementary Teacher Education. The data were gathered through e-questionnaire, LMS analysis, and document analysis. The result showed that the ITS infrastructures or LMS, Content Management, and Course Management were the component of e-learning that need to be improved.
\end{abstract}

Keywords: e-Learning, e-Learning Components, teacher education

\section{INTRODUCTION}

Information and Communication technology has rapidly developed and affected human activities, especially the internet, has become such a primary need. The internet has affected and changes the way of education, especially teaching and learning activities. The use of an internet transforms the interactions of students and teachers from face to face learning to online platforms of teaching and learning to set, so-called e-learning. In e-learning, students can do learning activities anywhere anytime or what so-called ubiquitous learning environment [1] [2].

The 21st-century demands for every teacher or lecturer to use media technology encourage students to study independently, collaboratively, creatively, and critically to solve problems. E-learning has been widely implemented in any educational institutions, schools, colleges, and universities. Even the Ministry of Research and Higher Education has a program called SPADA, which allows any students or lecturers to access learning resources online.

The implementation of e-learning is inevitably demanding. Yet, to do so, a university should comprehend the components of e-learning. Based on previous studies, experts have different opinions about the elements or components of effective or successful e-learning. The components include audiences, course structures, page design, content engagement, and usability [3], activity, scenario, feedback, delivery, context, and impact [4].

Recently, Esa Unggul University implemented e-learning, especially the department of Elementary Teacher Education. Started at the beginning of 2018, e-learning has brought many 
issues and discussions among lecturers and students. Many senior lecturers resisted teaching students in the e-learning setting. They questioned the quality of learning in terms of student understanding of the payroll of the teaching. While, in line with lecturers' concerns, students were also worried about how they will understand the courses. Now, the implementation of elearning in Esa Unggul University has been one year. Thus, this research aimed to investigate to what extent factors or elements or components affecting the implementation of e-learning in Esa Unggul University, especially in the department of Elementary Teacher Education, for lecturers to develop and improve e-learning.

\section{METHOD}

This research used the case study method to gain the result and conclusion. The data of this study were gathered from 70 students in the department of Elementary Teacher Education from Semester 2 to semester 7. To ensure the validity of research, data resource triangulation was employed.

The data were gained through e-questionnaire from students. Students answered assignments chosen randomly, and analysis of the LMS. The e-questionnaire used Google form as the platform and questioned about students' background and the implementation of elearning with 39 questions. There were 4 open-ended questions on the questionnaire. Of 70 students, 50 answered the questionnaire.

The three instruments were to answer the research questions: What are the factors/elements/components influencing the implementation of e-learning and the second question: to what extent do the factors influence the implementation? Moreover, the third question: what needs to be improved and developed for e-learning?

\section{RESULT AND DISCUSSION}

Answering the research questions, the finding showed that components or elements of elearning were related to each other. The following were the explanation of each component of e-learning.

The first component of e-learning is audiences, which means students, a critical factor in the process of e-learning. What audience means is student expectations, learning abilities, available hardware/software, job responsibilities, and preferences. Among those aspect audiences, the research found out that $79.60 \%$ of students meet their expectations, in terms students know what is to expect from the course and know the level of their competence after finishing the course. It could be because the students read the syllabus upload on the LMS. Yet, in terms of the knowledge and skill gained, the students concerned more about the skill since e-learning provides more theory than practices.

Regarding the hardware and software, the students agreed that they all have devices (computer or mobile phone) for accessing the e-learning. It is interesting to see the results that more than a quarter of students do not know the assignment of the course. Regarding the preferences, $37.5 \%$ of students agreed that the e-learning meets their learning styles. The LMS provides learning resources with modules and videos. It is easy for auditory and visual learning styles, yet not for the kinesthetic learning style.

The second component is course structure, which is related to the flow of the course, the sizes of modules, exercise or activity, and pictures or graphics. The flow of the course is easily followed $(55.1 \%)$ since it is managed in such a list, starting with modules, videos, links, and activities. Yet, more than half of the students (66.7\%) did agree that the size of the modules is too long. It is required for a course of 2 credits with 15 pages minimum. The ideal number of 
modules is about 8-10 pages [3]. However, the long page of modules does not discourage them from reading. The result shows that $49 \%$ of students affected by the long sheets, which means $51 \%$ of students still read them.

The third component is page design, including navigation intuitive, appearance, a balance between text and graphic, consistency, and ease of scanning information. In this page design, the e-learning has simple and ease of information search. The results show that $85.70 \%$ agreed that the page design of e-learning is simple and easy, yet not attractive $(59.20 \%)$. The unattractive page design could be because of the inconsistency of fonts. The results show students also agreed that the e-learning is inconsistent in using fonts (32\%). The modules students read have more texts, instead pictures or graphics. The results show that $75.50 \%$ of students agreed on the modules.

The next component is content management, including using a hyperlink, an interactive graphic, additional options or choices, incorporating quizzes and tests, focus, and fun activities. The results show that $87.80 \%$ of students agreed that e-learning always has a hyperlink. The hyperlink put in the e-learning is mandatory as additional resources for students. Yet, the hyperlink does not help the student to understand the course according to $24.50 \%$ of students. The results show that students $(57.10 \%)$ still can proceed to the next chapter, although they do not master the previous chapter or have not finished the assignment. On the LMS, every chapter is identified as the date of the chapter so that students can access it. Yet, to do the assignment of every chapter, students have to complete the quizzes.

Regarding the fun activities, less than half of the students (49\%) agreed that the e-learning activities are fun. On the LMS, every chapter of the course was managed as a list of activities, starting with modules students have to read, videos, hyperlink, followed by quizzes, and the last assignment. That is such a monotonous activity of e-learning every week.

Usability is the fifth component of e-learning. Usability means that the e-learning works appropriately. Only $22.40 \%$ of students agreed that the e-learning works appropriately. It means that almost $80 \%$ of students disagree about that. Students have difficulties in accessing the e-learning due to all students' access the e-learning at the same time. The most critical success of e-learning in university was IT infrastructure [5] [6]. Yet, they love e-learning due they can access anywhere and anytime. The next component is the scenario, which means that the content of learning can be contextualized. The results show that $50 \%$ of students agreed that the content of learning in e-learning could be contextualized.

Giving feedback is viewed as the last component, including the timing and appropriateness of feedback. Of students, $37 \%$ mentioned that they received immediate response/feedback. The lecturers may not give direct feedback due to they manage the time of every chapter for a week. They were suggested to do feedback on every Sunday. It is a more interesting fact that the feedback students gained was out of the task they have completed. It can be assumed that the lecturer did not read what the student have accomplished the tasks.

Regarding the component that should be improved in e-learning, the results show that the IT infrastructure was the main component that has to be grown or developed. Of the students, $64 \%$ mentioned that the network, the IT infrastructure should be fixed. It means that the component of usability is the main factor affecting the e-learning. The error of the LMS brought about other problems of e-learning. The other components that should be developed are course-related components, including content management and course structure. In content management, the quizzes and assignments are the crucial matter to be uploaded timely. The course structure, in terms of the clarity of the modules and the activities, becomes the concern of e-learning. 


\section{CONCLUSION}

From six factors that affect the implementation, the component of usability is the main factor affecting the implementation of e-learning, the main concern about the usability is that the e-learning works properly. Following the usability is a content management and the course structure.

\section{References}

[1] Z. Zainuddin and C. M. Keumala, "Blended Learning Method Within Indonesian Higher Education Institutions," J. Pendidik. Hum., vol. 6, no. 2, pp. 69-77, 2018.

[2] B. Cope and M. Kalantzis, "Ubiquitous learning: An agenda for educational transformation Ubiquitous Learning: An Agenda for Educational Transformation," in Proceedings of the 6th International Conference on Networked Learning, 2008, pp. 576-582.

[3] S. S. Gautam, "Components and benefits of E-learning system," Int. Res. J. Comput. Sci., vol. 3, no. 01, pp. 2014-2017, 2016.

[4] A. R. Brown and B. D. Voltz, "Elements of Effective e-Learning Design," Int. Rev. Res. Open Distance Learn., vol. 6, no. 1, pp. 1-9, 2005.

[5] S. K. Basak, M. Wotto, and P. Bélanger, "A Framework on the Critical Success Factors of E-Learning Implementation in Higher Education: A Review of the Literature," Int. J. Educ. Pedagog. Sci., vol. 10, no. 7, pp. 2409-2414, 2016.

[6] Y. D. Asalla, L.K., Putri, M.R., Pradipto, “"The critical success factor of E-learning in higher education: A systematic literature review," in International Conference on Information Management and Technology (ICIMTech), 2017. 